\title{
WAS AUNT JANE A SHOPLIFTER?
}

\section{DAVID PUGSLEY*}

\section{ABSTRACT}

This article thoroughly re-examines Aunt Jane's prosecution for shoplifting in the light of the three pamphlets published in the week after the trial, her own letters, contemporary local newspapers, and contemporary rules of evidence and criminal procedure. It concludes that the verdict of not guilty was correct and that the prosecution witnesses were guilty of perjury.

Keywords: Jane Austen; Leigh Perrot; shoplifting; Assizes

\section{Introduction}

Jane Austen's mother had an elder brother, James Leigh (1736-1817). ${ }^{1}$ In 1751, at the age of fifteen, he inherited an estate in Oxfordshire, worth $£ 5,000$ a year, under the will of his great uncle, Thomas Perrot, and added Perrot to his surname. He sold

1 His father was the Rev Thomas Leigh, Fellow of All Souls and Rector of Harpsden, Oxfordshire. His uncle was Theophilus Leigh, Rector of Adlestrop, 1718-1762, and Master of Balliol for fifty years from 1727 until his death in 1785, aged ninety one. See Balliol College Annual Record 2017, 42-47.

* Hon Archivist of the Western Circuit. The Western Circuit consists of the counties of Hampshire, Wiltshire, Dorset, Devon, Cornwall, Somerset, Bristol and, since 1971, Gloucestershire. From the Middle Ages until 1971 two High Court judges travelled round this circuit twice a year. Since 1971 two High Court judges act as Presiding Judges on the circuit. The Western Circuit is also the organisation of barristers who practise on the circuit, over 1200 of them. 
that estate and bought Scarlets, near Reading. In 1764 he married Jane Cholmeley (1746-1836). I shall refer to them as Uncle James and Aunt Jane. ${ }^{2}$

Uncle James had never had to work for his living. He took very little physical exercise for the rest of his life. He did not hunt, or shoot or fish, or ride or travel. $\mathrm{He}$ had no children to keep him active. He suffered badly from gout. They spent a lot of their time at Bath, where they moved into no 1, Paragon Buildings, in 1795. It was a large house and a visitor in April 1799 talks of going to a party there: "eight tables, ninety people."

Jane Austen and her mother came to stay in Bath in May and June 1799. She reported that Uncle James had over-walked himself and could now only travel in a chair, but a week later he was getting better again. She went to a cheap shop in Bath Street where gauzes were on sale at only $4 /-$ (= 4 shillings) a yard, "but they were not so good or so pretty as mine". In 1797 William Smith had been advertising his cheap haberdashery warehouse at no 1, Bath Street and "new cloak gauzes from 3/to $4 /$ - per yard". ${ }^{3}$ That was probably where she went. ${ }^{4}$ It was certainly where Aunt Jane went on Thursday 8 August.

\section{The card of white lace}

They left Paragon Buildings together, but Uncle James was walking very slowly and Aunt Jane went on ahead to do some shopping and promised to come back to meet him later. At no 1, Bath Street, she was served by Elizabeth Gregory, who was in charge of the shop, and bought some black lace. Gregory called her shopman, Charles Filby, to measure the lace, work out the price, pack up the parcel and take the money, which he did. Aunt Jane left the shop with the parcel in her hand and went back to meet Uncle James, who was not far away. They did some more shopping and were returning down Bath Street sometime later when Elizabeth Gregory rushed out of the shop and accosted her and asked her if she had some white lace in the parcel as well as the black lace which she had bought. She handed over the parcel, which Elizabeth Gregory opened and found a card of white lace inside. ${ }^{5}$ She took the white lace and went back into the shop. They continued on their way home, but they

2 I am reminded of John and Fanny Dashwood in Sense and Sensibility. John inherited from his great uncle, and from his mother (half when he came of age and half at the death of his father), and his marriage added to his wealth. If Fanny had been accused of shoplifting I can imagine her behaving like Aunt Jane, and if she had spent months in prison before her trial I can imagine him behaving like Uncle James.

3 Bath Chronicle, 29 Jun 1797.

4 But there was another cheap haberdashery warehouse at no 13, Bath Street, run by R Arnell, advertised in the Bath Chronicle from Dec 1796 to Dec 1800. Both shops bought their supplies from the same warehouse in London at 173 Fleet Street.

See Genesis, ch 44. 
had not gone very far when Charles Filby caught up with them, near Bath Abbey churchyard, and asked their name and address. Uncle James said they lived at no 1, Paragon Buildings, and his name was on the front door.

That was Thursday afternoon. Nothing more happened until Monday evening, when Aunt Jane received an anonymous letter addressed to Mrs Leigh Perrot, Lace dealer, no 1 Paragon Buildings, containing these lines: "Your many visiting Acquaintance, before they again admit you into their houses will think it right to know how you came by the piece of Lace stolen from Bath Street a few days ago. Your husband is said to be privy to it." ${ }^{\prime 6}$ And two days later, on Wednesday $14^{\text {th }}$, she was summoned before the Mayor and the magistrates at the Town Hall and found that Filby and Gregory had given evidence on oath: Filby that he had seen her take the white lace, and Gregory that she had found the lace worth 20/- in her possession. She was therefore sent to the County Gaol to await trial at the next Assizes.

\section{Assize towns and dates}

Since the Middle Ages two High Court judges had come round the Western Circuit twice a year, in March/April and July/August, to hear civil and criminal cases at the Assizes. If a prisoner was too late for one session of the assizes, he or she would have to wait for the next. If she was too late for the summer assizes she would have to wait nearly eight months for the next spring assizes. ${ }^{7}$ In 1799 the summer assizes for Somerset had been held in Bridgwater, beginning on 27 July, and the judges had moved on to Bristol on 1 August. It was too late for Aunt Jane.

In most counties there had been only one or two regular assize towns. Somerset was different. In the Middle Ages the assizes had been held at Ilchester, and the County Gaol was still there. Sometimes they were held at Chard. In 1672 and 1681 the summer assize was held in Bath. At the end of the eighteenth century the spring assize was held in Taunton and the summer assize alternately in Bridgwater and Wells. And that is why Aunt Jane, having been accused of shoplifting in Bath, was sent to the County Gaol in Ilchester and tried at the following spring assizes in Taunton.

\section{$4 \quad$ Ilchester gaol}

Uncle James went with her and stayed with her the whole time in spite of his ill health. They were not treated as common prisoners, but paid to stay in the governor's house. But they had to share it with the governor and his family, and to put up with "Vulgarity, Dirt and Noise from Morning to Night. Cleanliness has always been

6 Jane Leigh Perrot's letter to her cousin, Montague Cholmeley, 11 Sept 1799, printed in Somerset \& Dorset Notes \& Queries, vol 18, Mar 1924 at 5.

7 This system continued until 1879 when a system of four assizes a year was introduced. 
Perrot's greatest delight, and yet he sees the greasy toast laid by the dirty Children on his Knees, and feels the small Beer trickle down his sleeves on its way across the table unmoved. Mrs Scadding's knife well licked to clean it from fried onions helps me now and then". ${ }^{8}$ It is reminiscent of scenes in the Price household in Portsmouth when Fanny Price returned there from Mansfield Park, and indeed Jane Austen may have drawn her inspiration from the events in Ilchester Prison. ${ }^{9}$

\section{Taunton assizes}

The Taunton Assizes opened on Thursday 27 March and lasted three days. This was serious business. The court sat for long hours, and disposed of cases expeditiously. Four prisoners were condemned to death (two for burglary, one for assault and robbery, and one for sheep-stealing) and were in fact hanged at Ilchester on 9 April. Three more were sentenced to seven years transportation, and one to two years in prison (all for theft). If Aunt Jane had been convicted she might have been hanged, ${ }^{10}$ or transported to Australia. ${ }^{11}$

The assizes were also a great social occasion in a period when there was otherwise very little public amusement or entertainment. The nobility, gentry and respectables of the county converged on Taunton from all directions. The price of beds doubled. A handsome new theatre had just been completed in Silver Street, and there were performances every night during the assizes. There were dinners and parties and dances. There was an Assize Ball on the Friday night, before Aunt Jane's trial on the Saturday. The trial for shoplifting, for which the sentence could be death, and involving the leading silks on the Western Circuit, ${ }^{12}$ was the icing on the cake,

8 Letters to her cousin, Montague Cholmeley, 10 Oct and 10 Nov 1799, reprinted in Somerset \& Dorset Notes \& Queries, 1924, 7 and 59.

9 Ives 1980: 25-32: "Rebecca's puddings, and hashes, brought to table with half-cleaned plates, and not half-cleaned knives and forks." "The table cut and notched by her brothers, where stood the tea-board never thoroughly cleaned, the cups and saucers wiped in streaks, the milk a mixture of motes floating in thin blue, and the bread and butter growing every minute more greasy than even Rebecca's hands had first produced it." (The quotations come from Mansfield Park, chapters 42 and 46 respectively.) But I disagree with him (at 26) and Halperin 1988: 32, that Aunt Jane was the model for Mrs Norris. They are two totally different characters. Mrs Norris was an interfering busybody, very conscious of her poor relation status, and her sponging (near the end of ch 10) and her disposal of supernumerary glasses of wine and jellies in the domestic sphere are quite unlike shoplifting outside it.

10 Mary Jones, alias Murphy, was capitally convicted at the Old Bailey on 12 Sep 1771 for stealing twelve yards of thread lace, value 30/-, privately in the shop of Mr Foot, linen draper, in Ludgate Street. She was hanged at Tyburn on 16 Oct. "Had not her indecent Behaviour to the Judge and Jury prevented it, she probably might have been saved." (See Oxford Journal, 19 Oct 1771.)

11 But see, infra, under "Character Witnesses".

12 The civil court was not opened for business because the leading counsel who normally practised there were all busy in the criminal court. 
and it is said that 2,000 people turned up, ${ }^{13}$ though most of them will not have been able to see or hear anything.

\section{The trial}

Immediately after the trial three pamphlets were published recording the proceedings. A fourth pamphlet was advertised three weeks later, by Wm Legge, of the Temple, price eighteen pence, with marginal notes. ${ }^{14}$ I have been unable to find any copies of it or any other reference to it, which is a pity because the marginal notes may have commented on differences between the other three versions.

The modern reprints of the three published pamphlets all have the name Jane Cholmeley Leigh Perrot on the front cover, as if she were the author. And indeed the catalogue of the National Library of Australia expressly says that she was the author in all three cases. That cannot be right. The three accounts cannot even agree on how long the jury took to reach its verdict: seven minutes, about fifteen minutes, twenty minutes, nearly half an hour. And her full name, Jane Cholmeley Leigh Perrot, does not appear on any of the reprinted title pages. I can only think that it was manuscript on her copies of the pamphlets and that she was the owner, not the author.

The first pamphlet was published in London, price 1/-, and an extract from it appeared in the Bath Chronicle the following Thursday. The title page says: "The trial of Mrs Leigh Perrot, wife of - Leigh Perrot, Esq." Apparently the author did not know his Christian name. So it cannot have been Aunt Jane. He talks of assizes holden at Taunton; describes the Assize Hall; says that the Nisi Prius Court was not opened for business; and that all the Counsel on the Circuit surrounded the table of the Crown Bar. He left the court after the judge's summing up, without waiting for the verdict, and he did not know how long they took to reach it. I think that must have been one of the barristers, who was in a hurry to return to London at the end of the circuit. There was no Spring Assize at Bristol at that time; he had been away from home on circuit for four weeks; and he wanted to get back as soon as possible. I think it may have been Jekyll, one of the junior counsel for Aunt Jane, who had read out her unsworn statement when her voice failed her so frequently.

The second pamphlet was published in Bath, price $6 \mathrm{~d}$. An extract from it appeared in the Exeter Flying Post the following Thursday, and a second edition a week later. It was copied by a number of local newspapers and by the Lady's Magazine; or Entertaining Companion for the Fair Sex, Appropriated Solely to Their Use and Amusement for April 1800, published on 1 May: volume 31, pages 171-176, with the

13 Borowitz 2016: 303 says that the Assize Hall seated 2,000 and was filled to capacity. In fact nearly all of them had to stand, and "many hundreds of them could not possibly hear a word that was said, and were almost pressed to death, and suffocated with the heat, merely for the satisfaction of seeing the Criminal Court at a distance". (London pamphlet, see infra.)

14 Bath Chronicle, 24 Apr 1800. 
well-known portrait of Aunt Jane, which was engraved specially for the magazine. It was printed and sold by W Gye, Market Place, Bath. His name occurs several times during the course of the trial in the other pamphlets, but only once here (p 8), and it is omitted altogether in the Lady's Magazine. We do not know who the shorthand writer was, perhaps the reporter from the Exeter Flying Post. ${ }^{15}$

The third pamphlet was published in Taunton, on 8 April, price $2 /-$, and sold by all the Booksellers in Bath and Bristol. The editor was John Pinchard, Attorney, of Taunton, ${ }^{16}$ and it contains his short hand notes of the trial. The advertisement in the Bath Chronicle ends with a note: It is necessary to apprize the Public, that a Person at Bath, (a Party interested in the Prosecution) applied to the Editor for his Manuscript; which request not being complied with, a Sixpenny Account is, it seems, to be published to-morrow, in order to forestall the above. The advertisement at the beginning of the pamphlet itself is clearer: Unconnected, and unacquainted, with either of the parties, he gives the Trial without comment or embellishment; and pledges himself that he has not intentionally either added to it, or omitted, any word which can materially affect its accuracy. ${ }^{17}$ Three pages later we find that the second count of the indictment stated that the lace was the property of William Gye and Lacon Lamb. The other two pamphlets did not mention their names at this point.

\section{The case for the prosecution ${ }^{18}$}

After the opening formalities the leading counsel for the prosecution, Vicary Gibbs, $\mathrm{KC},{ }^{19}$ addressed the jury. At the end of his speech he anticipated that the defence would be either a mistake on the part of Filby, in putting the white lace in the same parcel with the black; or that it was a malicious prosecution for the purpose of extorting

15 The Pickering \& Chatto catalogue 786 offered a first edition for $£ 7,500$ and added that on a blank leaf inserted between the title page and the first page of the text there was a contemporary manuscript note: "Filby, who is the most prominent in this Prosecution of the Milliners against Mrs Perrot, was a Bankrupt when living in St Paul's Church Yard, London, under the Firm 'Terry and Filby', and for some cause could never get his Certificate. It was even said that something of the same sort had been attempted, to extort to prevent the exposure (as in this case) of a Prosecution. Even this short account of the Trial (a partial one) seems to point this out - as the great first cause - !"

16 For many years Chief Clerk to the Magistrates. He died in 1842, aged seventy eight.

17 The Brick Row Bookshop offered a first edition for $\$ 4,500$, adding: Contemporary ink signature on the title page of William Burgh, who has written in the margin of page 16, commenting on the proceedings: "Why did he not challenge it then? There was a Possibility of a Mistake, the opportunity of rectifying it should have been given. It now looks as if she was suffered to take it away in order to ground a malicious prosecution, or with a hope to be silenced by Reward."

18 The case for the prosecution is most conveniently set out in the Gye pamphlet, $\mathrm{p} 4$. It does not mention Gye.

19 A future Attorney General, Chief Baron of the Court of Exchequer, and Chief Justice of the Court of Common Pleas. 
money from the Prisoner's husband. In that case all the prosecution witnesses must be perjured. That could not be right, he said, because the witnesses went to the Town Hall immediately after the transaction to report the theft to the Town Clerk, the Deputy Town Clerk, and to everyone they met. "It was then impossible to recall the report. If, therefore, the facts are proved, can it (said he) be believed that the charge is fabricated?"

The witnesses for the prosecution were Elizabeth Gregory, who was in charge of the shop; Charles Filby, the shopman; and Sarah Raines, an apprentice. A shopwoman called Leeson was also present at the time but was not called as a witness.

According to them, when Aunt Jane entered the shop, Filby was at the top end behind the left hand counter near the door measuring a box of white lace. She went to the far end of the counter to look at some black lace with Elizabeth Gregory, and she chose the lace she wanted. Gregory called Filby to come and measure the lace, which presumably cost so much a yard, and the price came to $11-19 /-$. At the same time she called Raines to put the rest of the black lace into the box and to put it away, which she did.

Filby wrapped the black lace round a small card and put it in a piece of whited brown paper which he took from under the counter close by him (Pinchard, 15). He rolled the bought lace on a small piece of card, some paper was close by, put the lace in it and folded the paper up (Gye, 11). He rolled up the lace on a small piece of card, and taking up a piece of paper close by him, he folded up the card of black lace in the paper (Jekyll, 14). Sarah Raines said that he put what he had measured on a small card and put it in paper; she did not know where he took the paper from, as he did not go from the place where he was standing to get it. There was not anything else in the paper (Pinchard, 27). On cross-examination she went further. All the time she was absent from her work she was employed in putting away the black lace which her attention was principally engaged in. She admitted that there was nothing particular to draw her attention in the manner of Filby's putting up the black lace, and that she saw him every day putting up parcels. She did not then pay any particular attention to him, nor did she observe particularly from whence he took the paper to wrap up the parcel in (Pinchard, 28-29). There was nothing particular in the manner of Filby's putting up the parcel to attract her attention; and she did not know where he got the paper from to wrap up the parcel (Jekyll, 22).

Aunt Jane paid with a $£ 5$ note. Filby went to get the change. When he came back he found that she had moved from the place where he had left her and was standing at the top end of the shop, looking back, and with her left hand near the box of white lace. When he took the change to her he saw her left hand come out of the box with a card of the lace in her hand. He saw the corner of the card. It was partly concealed by her cloak. The black lace was in her right hand. He gave her the change at that end of the counter nearest the door; he laid it down on the counter, and she took it up with her right hand, in which the black lace was. She then asked him where Mrs 
Smith was, when she would be at home, and some other questions, and then left the shop (Pinchard, 16-17). ${ }^{20}$

When Aunt Jane had gone Filby stayed in the shop for two or three minutes chatting with Sarah Raines and Miss Leeson and then went down to Miss Gregory who was in the kitchen having her dinner. He did not examine the white lace box at that time (Pinchard, 17; Gye, 12). ${ }^{21}$

After Filby had spoken to her Gregory came back up into the shop and stood at the door (Pinchard, 28, Sarah Raines). In about a quarter of an hour after she came up, she saw Mrs Leigh Perrot in the street, on the other side of the road, with her husband (Pinchard, 7). On cross-examination she said about five minutes after she came up. She could not say exactly how long it was; never has since, at any moment, been able to say exactly what time had elapsed (Pinchard, 11).

She crossed the road and accosted them. "Pray, ma'am, have not you a card of white lace as well as black?" "No, I have not a bit of white lace about me." "See in your pocket, ma'am." "If I have, your young man must have put it up in mistake." Gregory said that Prisoner trembled very much, was much frightened, and coloured as red as scarlet (Pinchard, 8). She handed over the paper parcel to Gregory, who opened it and saw the card with white lace, and the black lace over it. The black lace card was about an inch shorter than the white lace card. She took out the white lace and looked at it. "Yes, it is mine; I will swear that to be the shop mark." Aunt Jane repeated that the man must have given it in mistake. "Tis no such thing, tis no such thing; you stole it, you are guilty." Uncle James said, "She did not," or something of that sort. Gregory took out the white lace and returned to the shop with it.

She called Filby up from the kitchen, and after consulting with her he went out to look for Mrs Leigh Perrot, whom he found with her husband at the corner of the Bath Abbey churchyard. Filby asked him his name. He answered that he lived at no 1, Paragon Buildings, and his name was on the door. Filby went there directly and saw the name.

He then went to Gye's, and afterwards went with Miss Gregory to the Town Hall (Pinchard, 18). This visit to Gye's by Filby is not mentioned in Gregory's evidence or in the other pamphlets; but all agree that the lace was in the possession of Mr Gye one night only and he returned it to her the following day.

20 See n 16, supra.

21 This is very strange. If he had seen the card of white lace in Aunt Jane's hand, why did he waste three minutes talking to the girls before going down to tell Miss Gregory in the kitchen? See the case reported in the Manchester Courier, 15 Jul 1826: James Tinley went into Samuel Lowe's shop and asked to buy two pieces of ribbon. When Lowe turned round to get his yardstick he saw the prisoner put his hand into the drawer. He immediately charged him with the theft, upon which he pulled out a piece of ribbon from his pocket, and returned it. He was then searched and another piece of ribbon was found, together with a large quantity of items of jewellery stolen from another shop. 
Gregory and Filby went to the Town Hall to lay an information, but the Mayor and the Magistrates had already left because they were busy with the soldiers who were passing through the town on their way to Holland. They went every day until the following Wednesday, when they were finally able to lay the information.

\section{The case for the defence}

Aunt Jane pleaded Not Guilty. What was the case for the defence? The short answer is that there was no direct defence. First, she, the prisoner, could not give evidence on oath in her own defence. So she could not challenge the prosecution account of events in the shop. Secondly, Uncle James, her husband, could not give evidence on oath either. So they could not challenge the prosecution account of events in the street. ${ }^{22}$ Thirdly, defence counsel were not entitled to address the jury; they could only examine and cross-examine witnesses. So they had no opportunity to set out the case for the defence in reply to the statement of the case for the prosecution. ${ }^{23}$ Fourthly, the defence were not entitled to see the depositions of the witnesses for the prosecution, their sworn statements before the Magistrates. ${ }^{24}$ So cross-examination had to be conducted to a large extent in the dark. It could not be prepared before the trial. $^{25}$

22 "The more I reflect on the diabolical Set that swore such abominable Falsehoods the less I wonder at the Numbers that swing every Year - indeed I am almost led to fear that many Innocent People suffer from false Oaths ... by timing it when I had only my Husband with me they were sure that I could have no Evidence against them." (Notes \& Queries, 135.) In Jan 1754 Joshua Kidden was capitally convicted for robbing Mary Jones, Widow, on the highway, of a guinea and some silver, and was hanged at Tyburn. On 1 Mar Mary Jones and three friends divided up the reward of $£ 40$ given by statute for the conviction of a highway robber. Five months later it was discovered that the whole thing had been a conspiracy to claim the Blood Money. All four were tried for murder at the Old Bailey, and convicted. These extraordinary rules of evidence in capital cases were not reformed until 1898, and there was no appeal from the verdict of a jury until 1908. The members of the jury were considered to represent the people, and when the people had spoken, that was that.

23 Hence they could not contradict Vicary Gibbs' assertion that once the alleged theft had been reported to the Town Hall it could not be recalled. This was a private prosecution which could have been stopped at any time. See, also, Mackinnon 1937: $40 \mathrm{n}$ 1. Aunt Jane was aware of this possibility: "If Filby had gone off the very day before the Trial, we should have lain under the Stigma of having bought him off without a possibility of Clearing ourselves." (Notes \& Queries, 135.) This rule was not reversed until the Prisoners' Counsel Act 1836.

24 "At present the depositions of witnesses taken before the Magistrate are sent to the judge who presides at the trial, but are not allowed to be seen by the prisoner or his Counsel. The crossexamination of these witnesses is, therefore, conducted under circumstances of no ordinary difficulty, for the Counsel has no means of cross-examining a witness upon his statements before the Magistrate, and of showing in that manner the difference between his evidence at one time and at another." See Bell's Life in London, 15 Jun 1834.

25 This rule was reversed by the Prisoners' Counsel Act 1836, s 4: "All persons under trial shall be entitled to inspect, without fee or reward, all depositions that have been taken against them and returned to the Court before which their trial shall take place." 


\section{Aunt Jane's unsworn statement}

Aunt Jane could not give evidence on oath in her own defence, as we have already seen. But she was entitled to make an unsworn statement. This was not evidence and was not subject to cross-examination. It was not normally used to enter into the facts of the case but to make a plea for justice and mercy.

She had prepared a written version of her speech. After the trial she made a copy of it which she sent to her cousin Montague Cholmeley. ${ }^{26}$ When she attempted to address the Court she was so agitated that her voice failed her several times in the first few sentences and the court had great difficulty in following what she was saying and the short hand writers reported it differently. ${ }^{27}$

Jekyll was asked to sit next to her and to repeat what she wished to say. The changeover is clearly indicated in the London pamphlet: "Blessed (said she) in the affections of a most generous husband ..." After that all reports say very nearly the same thing. It is particularly worthy of note that all three omit the sentence: "I will only ask you whether to be found opposite to the Shop within the space of little more than half an hour, and with the Lace in my Hand, is like the conduct of a guilty person." It was in her text. Presumably it was not read out in court. There is one curious variant. She invoked "that God whom we all acknowledge and adore". So reported by Gye and Pinchard. The London pamphlet, followed by the Times and all the other newspapers, and the Lady's Magazine, has "that God whom you all adore". "I call that God to witness that I did not know that I had the lace in my possession, nor did I know it when Miss Gregory accosted me in the street. I have nothing more to add."

\section{The witnesses for the defence}

The defence could not challenge the evidence of the prosecution witnesses directly, but they could cast doubt on it indirectly by showing that Filby was an unreliable witness and that similar mistakes had been made on other occasions. They called John Crouch, a pawn-broker in Cripplegate, London. On cross-examination Filby had sworn that he had never had any dealings with Crouch. Crouch now swore that Filby and his brother had both done business with him in the years 1793 and 1794, but perhaps not more than once or twice.

26 Notes \& Queries, 103-104. She made at least one mistake in copying it out. In the sentence, I shall leave the task where I am certain it will be executed with justice and mercy, she left out the word task.

27 Her text said: "Placed in a Situation in every respect the most enviable." In Pinchard that became "the most eligible", in Gye "the most affluent", and in the London pamphlet "the most comfortable imaginable". 
Miss Blagrave gave evidence that on 19 September she had bought a veil in the shop from Filby. When she got home and opened the parcel she found that there were two veils in it. She took the second one back the following day and was never accused of having stolen it.

Mary Kent gave evidence that at the beginning of August she had bought four pairs of gloves in the shop, though not from Filby. When she got home and opened the parcel she found that there were five pairs in it and returned the extra one the following day.

\section{The character witnesses}

The defence then called fourteen character witnesses. The first four were the good and the great.

George Vansittart, Esq (1745-1825), of Bisham Abbey, made a fortune as a merchant in British India, reputed to be worth $£ 150,000$, and retired to Berkshire in 1776, a few miles from the Leigh Perrots. He was MP for Berkshire from 1784 to 1812. "There was frequent intercourse between their families ... he conceived her to be a person of honourable and religious principles, and incapable of any act of dishonesty."

Lord Braybrooke (Richard Griffin, $2^{\text {nd }}$ Baron Braybrooke, 1750-1825), of Billingbear House, Berkshire, was MP for Grampound, 1774-1780; Buckingham, 1780-1782; and Reading, 1782-1797. He succeeded to the peerage in 1797, and was Lord Lieutenant of Essex from 1798 until his death in 1825. In June 1780 he married Catherine, youngest daughter of George Grenville. Her father was Prime Minister, 1763-1765; her brother, William, was Prime Minister, 1806-1807; and her cousin, William Pitt, the younger, was Prime Minister, 1783-1801 and 1804-1806, that is, he was Prime Minister at the time of the trial. Lord Braybrooke "lived within a few miles of the Leigh Perrots, visited the family and knew them well. He always considered Mrs Leigh Perrot's character strictly honourable and unimpeachable".

Francis Annesley, Esq (1734-1812), was MP for Reading, 1774-1806, for half of that time with Lord Braybrooke. He was one of the trustees of the British Museum, and the first Master of Downing College, Cambridge, from 1800 until his death. "He used to dine four or five times with the Leigh Perrots every summer; lived about six miles from them; no one could have supposed that she could do anything dishonourable."

John Grant, Esq of White Waltham, bought Waltham Place in 1774, four miles from Scarlets. He was High Sheriff of Berkshire in 1780. They frequently visited and dined with each other. "Their fortune was ample, and there was no occasion for any appearance of meanness in her conduct."

With that support it is probable that if Aunt Jane had been convicted she would have spent a few months in prison and then received a free pardon from the King. In 
1799 Lieut Stevenson, who had been convicted of murder and sentenced to death in March at the Exeter spring assizes for his part in a fatal duel, received a free pardon from the King in September. Aunt Jane had a much stronger case.

The next two witnesses were clergymen. The Rev Philip Nind was vicar of Wargrave and Waltham St Lawrence and one of Lord Braybrooke's domestic chaplains. Scarlets was in his parish. He lived about two miles and a quarter from the Leigh Perrots. "No people attended the church more regularly than they did. He never could have suspected the Prisoner to have been guilty of such an action."

The Rev William Robert Wake was Vicar of Backwell, Somerset, Curate of St Michael's, Bath, and Chaplain to the Earl of Bristol. The Leigh Perrots lived in his parish in Bath. "They were constant attendants at the church. He was particularly pleased at their being generally at church in the afternoon, when very few people except tradesmen and servants attend the church. She would have been the last person to have committed such an action."

There were eight more witnesses, local residents and tradesmen, including a linen draper, a mercer and a jeweller, who gave evidence to the same effect.

\section{The judge's summing up}

Mr Justice Lawrence summed up the case for the jury for nearly an hour. His summing up is only reported very briefly in the three pamphlets. He went carefully through the evidence, but they had already reported what the witnesses had said and were not going to repeat it.

The three versions differ considerably and it is impossible to reconstruct what he actually said. In any case those who were listening, including the members of the jury, will have remembered or interpreted it differently.

The version in the Bath pamphlet (Gye) was the shortest. The judge emphasised her excellent character; he said that if they believed Filby they must convict; but they should bear in mind that she had returned to Bath Street so soon when she might have gone home and hidden the white lace; and he left the case with them.

The London pamphlet (Jekyll) was the most favourable to the prisoner. If they put their confidence in Filby the charge was proved; but the witnesses for the defence had cast doubt on his reliability as a witness and on his carefulness as a shopman; and she had passed the shop again within half an hour with the parcel in her hand. So many respectable persons had spoken of her high character. And he concluded: "If the felony has not been proved to your satisfaction, you will let that character have its due influence in favour of the prisoner, and acquit her."

The Taunton pamphlet (Pinchard) has the longest report, going on for four pages. The judge dwelt particularly on some material parts of the testimony given by the witnesses. We are not told what those material parts were, but it is possible to identify them. Pinchard's report is not a verbatim account of the proceedings but 
a set of minutes giving the substance of them. But at two points he sets out the question and the witness' answer verbatim, presumably because the judge drew them especially to the attention of the jury.

Bond cross-examined Filby (p 24):

"Q. You not only say then that you saw Mrs Leigh Perrot's hand in the box, but that you also saw the card in her hand under her cloak?

A. Yes, I did. I saw it distinctly hanging down under her cloak. ${ }^{228}$

He had already made this point in his evidence in chief (pp 16-17). Bond wished to underline it. And the question for the jury was simply whether they believed him when he said that he saw the card of white lace but did nothing about it. If they believed him they should convict.

The judge at the end of Jekyll's cross-examination of Sarah Raines (p 29):

"Q. You say he did not put any white lace in the parcel with the black. How could you know that, not being particularly observant?

A. I saw that he put in the black lace only.

Q. Are you certain of that?

A. Yes, my lord, I am."29

She had already admitted in cross-examination that her attention was principally engaged in putting away the black lace; that there was nothing particular to draw her attention to what Filby was doing; and that she did not see where he took the paper from to make the parcel. So the first question was a good one: how could she know that? She did not, and could not, answer that question.

We have no evidence about the demeanour of the witnesses when they answered the questions. When Gregory accosted Aunt Jane in the street she says that she trembled very much and turned bright red. We do not know anything about the body

28 The other two pamphlets agree in substance but do not have the Q and A form. After the trial was over Aunt Jane insisted that she did not have on any cloak. (Notes \& Queries, 103.) See Borowitz 2016: 318-319: "It would be hard to believe that the Leigh Perrots, promenading on one of the main streets of Bath where they were well known, did not come across a single friend or acquaintance on the day in question who could have testified that Mrs Leigh Perrot was not wearing a cloak. No such testimony was introduced." But she did not know on the day in question, 8 Aug, that she would need such testimony, and it was very unlikely that anyone would remember on 14 Aug, let alone on the following 29 Mar, what she had been wearing on that day. Gregory and Filby must have remembered what she was wearing in the shop, or they could not have found her so quickly and easily in the street afterwards. So why did she say that she was not wearing any cloak? I suggest that she was not talking about what she was wearing, but about what it was called. She was not wearing a cloak, functional and vulgar, but a cape, fashionable and respectable.

29 The London pamphlet is substantially the same and has the second Q and A verbatim, but not the first. That gives a totally different impression. The Bath pamphlet is much vaguer. 
language of the witnesses, but the members of the jury will have been able to watch it and draw their own conclusions.

The judge drew the jury's attention to the fact that Filby's evidence stood uncontradicted, ${ }^{30}$ except in one point of trivial consequence concerning his dealings with Crouch. It was corroborated by the testimony of Gregory that Aunt Jane had not waited for her change at the far end of the counter but had wandered off near the white lace by the door; and by the testimony of Raines that Filby had only put black lace in the parcel.

On the other side he emphasised her previous good reputation and the fact that she had returned and passed the shop with the parcel containing the lace in her hand, which was not the conduct of a guilty person; and the fact that she turned as red as scarlet was not an indication of guilt, anyone suddenly accosted in the street might have reacted in the same way. ${ }^{31}$

He said three times that the question was whether they believed or disbelieved the witnesses for the prosecution, and in case of doubt they should remember her very excellent character which should have great weight with them towards an acquittal.

The jury did not take long to return a verdict of Not Guilty.

\section{What really happened?}

Obviously the jury did not believe the witnesses for the prosecution. So what really happened? If Aunt Jane had been allowed to give evidence on oath, what would she have said? If her Counsel had been allowed to address the jury what might he have said?

When the card of white lace was found it was in the parcel underneath the card of black lace, which was about an inch shorter. Why was it in the parcel? And why was it underneath the black lace?

It must have been put there, either by Aunt Jane or by Charles Filby.

Why should Aunt Jane have put it there, where it was not even hidden, when she could have hidden it anywhere in her clothes, where she could not be searched in public? ${ }^{32}$ That seems unlikely.

Could Charles Filby have done it? We know where the white lace came from. It came from a box of white lace that he was measuring behind the counter near the door. We do not know where the brown wrapping paper came from. Sarah Raines openly admitted that "[s]he does not know where he took the paper from, but it was very near him, as he did not go from the place where he was standing to get it."

30 But it could not be contradicted, because Aunt Jane could not give evidence.

31 It might have been an indication of anger at a false accusation made in a public street.

32 See the case reported in the Taunton Courier, 6 Oct 1830, of the lady of very fashionable appearance and very elegantly dressed who concealed several yards of lace in her bosom. 
She confirmed that in cross-examination "[she] did not observe particularly from whence he took the paper to wrap up the parcel in". What Filby said is differently reported in the three pamphlets: "He put the black lace in a piece of whited brown paper which he took from under the counter close by him (Pinchard, 15)." "Taking up a piece of paper close by him, he folded the black lace in the paper (Jekyll, 14)." "Some paper was close by; he put the lace in it \& folded the paper up (Gye, 11)." Pinchard's account is more detailed than the other two, but does not contradict them. It is unlikely that he made up the extra details; it is more likely that they left them out because they did not think that they were important. We may conclude that the paper was "under the counter close by him".

That does not seem to have been the place where wrapping paper was usually kept or where Raines would have looked for it. That suggests that Filby had put it there himself.

When Gregory called Filby to come and measure the black lace he turned round and put the lid of the white lace box on the chair on which he had been sitting. While his back was turned he quickly put the sixth card of white lace on a piece of brown paper which was kept there. He then turned back and walked to the far end of the counter with his yardstick in one hand and the brown paper in the other, which he quickly put under the counter at that end. No one will have been paying much attention while this was going on.

He then measured Aunt Jane's black lace and wrapped it round a small piece of card which he quickly put on top of the white lace and wrapped up the parcel, while Raines came and put away the rest of the black lace. He did it so fast that Aunt Jane, who might have been watching, did not notice. Nor did Sarah Raines, who was paying attention to what she was doing rather than watching him.

And that is why the white lace was in the parcel underneath the black.

She paid with a $£ 5$ note, and while Filby went to get the change she wandered up to the other end of the counter. That must have looked rather suspicious. What was she doing? She could not tell the court.

Fortunately we have a letter, written to her cousin, Montague Cholmeley, on 11 September, just five weeks after the events, setting out her side of the case. ${ }^{33}$

It is true that this is not on oath and not subject to cross-examination. But it does not argue against the prosecution case, because she had not seen the depositions and did not know the details contained in them. She simply sets out the facts as she remembers them, and they were fresh in her memory.

On 8 August she went on ahead of Uncle James, who was going to catch her up later. She went in to no 1, Bath Street, and bought some black lace. While she was waiting for her change "I turned from the counter to the door to catch my Goodman 
who in going to drink his Water generally passed that way." She simply wanted to be near the door, not near the other end of the counter.

When she left the shop she went back the way that Uncle James usually came and had not gone far before she met him. They went together to the Cross Bath, stopped to pay a tradesman's bill, and proceeded through Bath Street to post a letter at the Post Office.

Now, where was that letter while she was in the shop? Was it in her left hand? That would explain why she did not bother to hide it or hurry to leave the shop. It would also explain why Filby took no notice of it. He knew that it was not the card of white lace, because he had put that in the parcel. He changed his story later on, as we shall see, but that is why he did nothing at the time.

When they came opposite the shop, Elizabeth Gregory rushed across the street and accosted her with these words: "I beg pardon, Madam, but was there by mistake a card of white lace put up with the black you bought?" Aunt Jane said she could not tell as she had not been home and the parcel had never been out of her hand and she had not opened it. She gave the parcel to Gregory, who opened it, and there was a card of White Edging which she took out saying "Oh, here it is," and went back to the shop.

So we have two different accounts of the event and the conversation in the street. Which is correct? If the Gregory version is correct, Aunt Jane had no reason to change it. But if Aunt Jane's version is correct, Gregory had to change it if she was going to prosecute for theft, because it was evidence of mistake. And that explains another oddity: if she accused them of theft in the street, why did she not ask them their name and address then and there, with a view to prosecuting them, which Filby did later on?

Aunt Jane could not comment on the Gregory version in court, but she did comment on it in a letter to Montague Cholmeley on 14 April, two weeks after the trial. ${ }^{34}$ She said she was feeling more calm - "but the more Calm I feel (tho' perhaps a contradiction) the more ruffled I am with all the people principally concerned in this most infamous Transaction". Commenting on the Gregory version she said: "Can anyone believe that all this could have been said to me in one of the most public streets in Bath, at two o'clock when everybody was passing to the Cross Bath to drink the Water and that no person should have heard it, which she says was the Case?" 35

Aunt Jane's version is more plausible.

If Gregory thought at that time that there had been a mistake, the next question is: What had Filby told her? Certainly not that he had seen the card in her hand

34 Idem 135-137.

35 The point had already been taken in court when Gregory was cross-examined by Dallas: Pinchard, 11; Jekyll, 12; omitted by Gye. 
underneath the cloak. Presumably that after Aunt Jane had left, and he had had two or three minutes conversation with the shop girls, he went back to work measuring the white lace and found that one card of white lace was missing. Hence Gregory's comment when the white lace was found: "Oh, here it is."

After that Filby went out and found the Leigh Perrots near Bath Abbey and asked their name and address, and then went to see William Gye. They decided to threaten prosecution in order to extort money from Uncle James. Filby, who now recalled that Aunt Jane had had something in her left hand, made up his new account of what happened and what was said in the shop. Gregory made up her new account of what happened and what was said in the street.

But the jury did not believe them.

\section{What happened to them all?}

Charles Filby left Bath and returned to London, where his name appears in bankruptcy proceedings for years to come.

Elizabeth Gregory was found dead in a wood at Luckham in $1815 .{ }^{36}$

William Gye died of an apoplectic affection in 1802. ${ }^{37}$

Mary Smith, Elizabeth Gregory's sister, who had been in Cornwall on 8 August, returned to Bath and ran the shop successfully at least from November 1799 to March 1807. ${ }^{38}$ William Smith died in $1803 .{ }^{39}$

Aunt Jane and Uncle James: I am tempted to say that they lived happily ever after. ${ }^{40}$ Their social position was unquestioned. It was even suggested that if he stood for Parliament at Ilchester at the next election he would stand a very good chance of winning. ${ }^{41}$ Members of the family often came to visit. About 1811 they moved into a much larger house at 49, Great Pulteney Street, on the other side of the river. They continued to divide their time between Bath and Scarlets, where he died on

36 Bath Chronicle, 14 Sep 1815.

37 Gloucester Journal, 26 Apr 1802.

38 Bath Chronicle, 21 Nov 1799, 19 Mar 1807. See Aunt Jane's letter to her cousin on 14 Apr 1800: "the Man is off and the Shop I hear must be ruin'd." This was side by side with the advertisement for the second edition of the Gye pamphlet.

39 Bath Chronicle, 8 and 15 Dec 1803.

40 In two items on the Jane Austen website in 2011 and 2012 Ellen Moody refers to another incident in 1805, but gives insufficient details of her source for us to form any judgment about it. Two incidents, each involving a single item, would not make Aunt Jane a kleptomaniac, even if they had been proved, which they were not. For a good example of shop-lifting mania see the Bath Chronicle, 29 Nov 1827. The prisoner was a medical doctor in good practice who had received a fortune of nearly $£ 2,000$ with his wife. He used to go about to shops and auction rooms wearing a large camblet cloak with a number of pockets inside. His house was full of silks, ribbons, plated ware and other items stolen from shops in Dublin. He was convicted of stealing three yards of linen and sentenced to seven years transportation. This is very different from Aunt Jane.

41 Notes \& Queries, 135. 
$28^{\text {th }}$ March 1817, aged eighty one (a few months before Jane Austen herself); and she died on 13 November 1836, aged ninety.

\section{BIBLIOGRAPHY}

Borowitz, Albert (2016) Crimes Gone By: 303 \& 318-319 (Cleveland, Ohio)

Halperin, John (1988) Studies in Fiction and History from Austen to Le Carré: 32 (Basingstoke and London)

Ives, Sidney (1980) The Trial of Mrs Leigh Perrot, Wife of James Leigh Perrot, Esq: 25-32 (two hundred copies for subscribers and five copies for libraries of deposit; printed and bound at the Stinehour Press, for the Club of Odd Volumes, Boston)

Mackinnon, Sir Frank Douglas (1937) Grand Larceny, Being the Trial of Jane Leigh Perrot, Aunt of Jane Austen: 40 (London)

\section{Additional bibliographic information}

Trial of Mrs Leigh Perrot, wife of - Leigh Perrot, Esq. No author named, perhaps Joseph Jekyll. Printed by JH Myers, no 2, Paternoster Row, for West and Hughes, no 40, Paternoster Row, and C Chapple, no 66, Pall Mall (London, 1800)

Trial of Jane Leigh Perrot at Taunton Assizes. No author named, perhaps William Gye. Printed and sold by W Gye, and to be had of the booksellers in town and country (Bath, 1800)

Trial of Jane Leigh Perrot, wife of James Leigh Perrot, Esq. Taken in court by John Pinchard, Attorney, of Taunton. Printed by and for Thomas Norris, White Lion Court (Taunton, 1800) 